\title{
FINANCIAL REPORTING IN THE LODGING INDUSTRY FROM THE SEGMENT REPORTING ASPECT
}

\author{
PhD Student Andor Pajrok, University of Pecs, \\ e-mail:pajrokandor@hotmail.com
}

\begin{abstract}
Quality of accounting reporting system reflects the accomplished development stage of the accounting information system and its ability to satisfy different external and internal accounting information needs. One of the most important sources of information about the efficiency of any business subject is financial statements. The paper considers the financial statements reporting requirements for the Lodging Industry, which are set in (beside of the IASB and the FASB regulation) Uniform System of Accounts for the Lodging Industry (USALI).

The aim of this paper is to disclose possibilities of Segment Reporting in the Lodging Industry enterprises to demonstrate the „true and fair view” of theirs financial situation. For business transparency, the most important accounting information are based on segment reporting standards. Enterprises in the Lodging Industry to satisfy external and internal users needs have to set up theirs financial statements according to requirements of IAS 14 and SFAS 131. Furthermore, USALI methodology has to be adjusted to the real organizational structure and real information requirements of particular company.
\end{abstract}

Keywords: the lodging industry, IAS

JEL Codes: $M 410$

\section{Introduction}

In our days, globalization is one of the most important factors which influence the companies' business condition. Into these "global village" casemaps quality information become the bases of successful business activities, furthermore so called external users: creditors, (potential) investors want to know the rate of return of their investments. One of the most important sources of this information is financial statements. Therefore adopting of the uniform, standard language for financial reporting is one of the preconditions for international capital flow.

The objective of this paper is to disclose possibilities of Segment Reporting in the Lodging Industry enterprises to demonstrate the ,true and fair view” of their financial situation. For business transparency, the most important accounting information is based on segment reporting standards. Enterprises in the Lodging Industry to satisfy external and internal users' needs have to set up their financial statements according to requirements of IAS 14 and SFAS 131.

\section{International Accounting Harmonization}

Investors constantly face economic choices that require a comparison of financial information. Experts [Sankaran and AlHashin (2006), Barlev and Haddad (2007)] stressed out that International Accounting Harmonization is an outcome of the globalization of financial markets and of economic integration. Its objective, as explained by the Financial Accounting Standards Board (FASB) is to provide internationally comparable accounting data. One way to improve comparability and transparability in financial reporting is to use „,international” accounting standards. 
The greatest efforts for harmonization of accounting standards have been made by Financial Accounting Standards Board (FASB) ${ }^{*}$, the International Accounting Standards Board (IASB) ${ }^{\dagger}$ and the European Union. The role of the International Hotel and Motel Association should be also mentioned here, which ensures the presentation of internal business results of the world hotel industry using the Uniform System of Accounts for the Lodging Industry.

The European Union drafted its expectations into the framework, which mean that the EU left Member Countries a degree of flexibility in the transposition of the accounting directives into national law by including several options within them. On 12th March 2002 the European Parliament approved the European Commission's proposed Regulation on financial reporting: all EU listed companies should prepare their consolidated financial statement in accordance with standards issued by the International Accounting Standards Board (IASB), starting no later than 2005. The Commission's proposals were based upon a Communication of 13th June 2000 entitled: EU Financial Reporting Strategy: The Way Forward.

At the joint meeting in September 2002, the International Accounting Standards Board (IASB) and the Financial Accounting Standards Board (FASB) agreed to work together to develop high quality, fully compatible financial reporting standards that could be used for domestic and cross-border reporting. The agreements' effects have become visible nowadays, in 2008, when the Security and Exchange Commission (SEC) accepted financial statement prepared according to requirements issued by IASB.

The Uniform System of Accounts for the Lodging Industry was published by the Hotel Association of New York City in an attempt to establish a uniform accounting system for member hotels. The first edition of the uniform system for hotels was issued in 1926. It was one of the earliest attempts by any industry in the United States to create guidelines for preparing accounting standards and financial reporting practices. The document reflects its cost accounting view, because the appearance of the document was the answer to the management needs. In 1961 the American Hotel and Motel Association developed a uniform system of accounts for small and medium sized hotels and motel (Kwansa et all, 1999). Up to this day the document was alive in more editions - in October 2006 the $10^{\text {th }}$ edition was published, which is, according to experts totally harmonized with the requirements of US GAAP.

The global convergence of accounting standards is increasingly moving ahead. Today more than 100 Countries allow or require the implementation of IAS/IFRS.

\section{Requirements of Accounting Information in the Financial Statement}

The Financial Accounting Standards Board (FASB) and the International Accounting Standards Board (IASB) emphasize that financial statement should provide information that is relevant to the decision-maker needs of investors, creditors and other users. According to the IASB framework "the objective of financial statements is to provide information about the financial position, performance and changes in financial position of an entity that is useful to a wide range of users in making economic decisions." $\$$ The Information to be useful to the decision-maker in Financial Statement has to fulfill the quality features. Qualitative characteristics are the attributes that make the information useful to users.

According to IASB framework the four principal qualitative characteristics are:

\footnotetext{
* In 1972 the Financial Accounting Standard Board was founded with the aim to create and develop the accounting standards.

${ }^{\dagger}$ On the $29^{\text {th }}$ of June 1973, in London the International Accounting Standard Committee was founded. The purposes of foundation were to develop a qualitative and understandable accounting standards, and to improve the adaptation of these standards.

${ }^{*}$ This, in turn, was derived from a Communication of 1st November 1995, Accounting Harmonization: A New Strategy vis-à-vis International Harmonization.

${ }^{\S}$ Framework for the Preparation and Presentation of Financial Statements, www.iasb.org
} 
- understandability,

- relevance,

- reliability, and

- comparability.

In practice balancing between qualitative characteristics is necessary. While the FASB points out that accounting information must be relevant, reliable, comparable and consistent ${ }^{* *}$, both, the FASB and the IASB suggest that if Financial Statement setters observe the standards and qualitative features in the process of preparation, then the Financial Station would give the "true and fair view".

The only difference between these two approaches is that the IAS framework additionally stresses the understandability of the information, while FASB finds it as a specific quality of users and not of the information, as the FASB discusses "Information cannot be useful to decision makers who cannot understand it, even though it may otherwise be relevant to a decision and be reliable. However, understandability of information is related to the characteristics of the decision maker as well as the characteristics of the information itself and, therefore, understandability cannot be evaluated in overall terms but must be judged in relation to a specific class of decision makers."

According to FASB between qualities features there could be set up a hierarchy - the relevance and reliability are the two primary qualities that make accounting information useful for decision making.

\section{Financial Reporting in the Lodging Industry}

Inside the Lodging Industry's enterprises I would like to focus on the Hotel Companies. The most general definition of a Hotel is that it is an establishment that provides paid lodging (usually on a short-term basis), serves food and drinks and offers other facilities. Instead of definition International Hotel and Motel Association (IH\&MA) gives some requirements that a Hotel has to satisfy, for example it has to dispose at least with 6 rooms. Similarly to the IH\&MA, the Word Tourism Organization (WTO) creates different qualitative groups according to the quality of services offered by Hotels.

The FASB Statement gives the general purpose of Financial Reporting, according to it financial reporting attempts to meet "the informational needs of external users who lack the authority to prescribe the financial information they want from an enterprise and therefore must use the information that management communicates to them".

The Statement, typically produced for external users are:

- Balance Sheet

- Statement of Income

- Statement of Stockholders' Equity

- Statement of Cash-Flow, and

- Notes

IAS/IFRS and US GAAP do not set the format for the Financial Statement, instead of that they prescribe what information they have to provide. Depending on the specific features and significance of an enterprise, and on the special requirements of particular standard, the enterprise can decide which items they will disclose within the Financial Statement and in the Notes.

Based on US GAAP, Uniform Accounting System (USALI) required that presentation of assets and claims to its assets (called liabilities and owners' equty) will be according to its liquidity preference. The expected balance sheet form satisfies the IAS/IFRS requirements too, because it allows liquidity preference if it increases the statements "true and fair view".

\footnotetext{
** Statement of Financial Accounting Concepts No. 2. „Qualitative Characteristics of Accounting Information”, www.fasb.org.
} 
The form and content of Income Statement can differ significantly depending on the preparation basis. According to the IAS 1 the minimum disclosed information should be: revenue, results of operating activities, result of financial activities, result of investment activities, dividend and net profit or loss. US GAAP leaves it up to enterprises to create the Income Statement format, depending on specific enterprise needs. USALI requires the classification of both revenues and expenses on the Income Statement by different departments. USALI requires the use of the costing method based on direct and indirect cost classification.

Following the US GAAP requirements USALI allow different ways to report the Statement of Stockholders' Equity. It introduces the concept of comprehensive income, which is defined as a change in equity of an enterprise during a period from transaction and other events and circumstances from non-owner sources. USALI requires the presentation of this statement only in cases where significant changes in equity accounts occurred in the period.

USALI provisions for the Cash-Flow Statement are the same as US GAAP. The content of the statement is regulated by SFAS 95: Statement of Cash Flow and IAS 7: Cash Flow Statement. The cash-flow statement can be prepared using the direct or indirect method. Both Accounting Boards (FASB and IASB) have expressed a preference for the direct method, because it gives useful information for predicting future cash flow. USALI format require to show the changes in the last three years, which improves the statements' quality, because users can analyse the trend.

IAS 1 requires disclosing in the note description of items, or detailed analysis of amounts from financial statement, in a manner which respects all enterprise's and industry's specific quality. USALI does not specifically regulate content and order of the notes, but specifies which information should be disclosed in the notes.

\subsection{Segment Reporting}

Managers faced that companies' environment has become more changeable than ever. Companies in order to achieve higher level of business success require adequate and accurate information. Financial information plays a very important role in the decision making process, because it helps managers to find necessary decisions and actions. This information can arise from management accounting. Segment reporting is the fundamental task of management accounting and is based on the IAS 14 or on the SFAS 131.

Both statements subscribe segment as a component of an enterprise. It is not a separate legal entity, but has ability of financial reporting.

IAS 14 distinguished Business and Geographical Segments.

- Business segment: A component of an enterprise that provides a single product or service or a group of related products and services and that is subject to risks and returns that are different from those of other business segments. Factors that should be considered in determining whether products or services are related include:
(a) the nature of the products or services;
(b) the nature of the production processes;
(c) the type or class of customers for the products or services;
(d) the methods used to distribute the products or provide the services; and
(e) if applicable, the nature of the regulatory environment, for example, banking, insurance, or public utilities.

- Geographical segment: A component of an enterprise that provides products and services within a particular economic environment and that is subject to risks and returns that are different from those of components operating in other economic environments. Factors that should be considered in identifying geographical segments include:
(a) similarity of economic and political conditions;
(b) relationships between operations in different geographical areas;
(c) proximity of operations; 
(d) special risks associated with operations in a particular area;

(e) exchange control regulations; and

(f) the underlying currency risks.

Contrary to the IAS 14, SFAS 131 is based on Company's structure and operation defined operating segment. It stresses out the Management responsibility at the disclosure of business result. Therefore it emphasizes its management approach.

Both standards set up the same requirements to reportable segments. An enterprise shall report separately information about a segment that meets any of the following quantitative thresholds:

a. Its reported revenue is 10 percent or more of the combined revenue,

b. The amount of its reported profit or loss is 10 percent or more of the combined

c. Its assets are 10 percent or more of the combined assets.

The result of harmonization process is that IASB issued IFRS 8 standard about Operating Segment, which become effective from $1^{\text {st }}$ of January 2009. It follows the US Boards Management's Approach.

In practice Segment appears as responsibility centers. Hotel can be considered as an Investment Center. Inside the whole enterprise there can be distinguished profit centers (according to the departments like lodging, food and beverage, and so on) and inside of profit centers there can be identified revenue and cost centers. At the end of the accounting period before preparing the Financial Statement each responsibility center contributes their budget.

The most important benefits of using USALI is that it emphasizes the determination of departmental income, from which direct and indirect expenses are deducted to arrive at income before taxes. The fundamental principle of responsibility accounting as a subsystem of managerial accounting is that cost are assigned to various hierarchical levels of management which are in charge of their control to make managers responsible for the difference between budgeted and realized (Garrison and Noreen, 1997, p. 389).

\section{Summary}

The aim of this paper was to bring attention to the Financial Reporting in the Lodging Industry and to find the place of accounting standards for the Hotel Companies in the process of International Accounting Harmonization. The study pointed out that USALI satisfies the standards required in IAS/IFRS and US GAAP.

\section{References}

1. Barlev, B, Haddad, J., R. - Harmonization, Comparability, and Fair Value Accounting, Journal of Accounting, Auditing\&Finance, Summer 2007, Vol. 22 Issue 3, p. 493-509.

2. Framework for the Preparation and Presentation of Financial Statements, available online in www.iasb.org.

3. Garrison, R., H., Noreen, E., W. - Managerial Accounting, $8^{\text {th }}$ Edition, Irwin.

4. International Accounting Standard No. 14. - Segment Reporting, available online at www.iasplus.com.

5. Kwansa, Francis, Schmidgall, Raymond S. - Uniform System of Accounts for the Lodging Industry, Cornell Hotel \& Restaurant Administration Quarterly, December 1999.

6. Uniform System of Accounts for the Lodging Industry, $9^{\text {th }}$ Edition, Educational Institute of the American Hotel \& Motel Association, East Lansing, Michigan, 1996

7. Sankaran, S., Al Hashim, D., - An Accounting Information System for Harmonization, The Journal of American Academy of Business, Cambridge, September 2006, Vol. 9 Num. 2., p. 249-256. 
8. Shellhorn, T., Gornik-Tomaszewski, S. - Implication of the IAS Regulation for Research into the International Differences In Accounting System, Accounting in Europe, Vol. 3., 2006, p. 187-217.

9. Statement of Financial Accounting Concepts, No. 2. - Qualitative Characteristics of Accounting Information, available online at www.fasb.org.

10. Statement of Financial Accounting Standards No. 131. - Disclosure about Segment of an Enterprise and Related Information, available online at www.fasb.org.

11. www.ahla.com. 